\title{
Geophysical characterisation of two segments of the Møre-Trøndelag Fault Complex, Mid Norway
}

\author{
A. Nasuti ${ }^{1,2}$, C. Pascal ${ }^{2,}{ }^{*}$, J. Ebbing ${ }^{1,2}$, and J. F. Tønnesen ${ }^{2}$ \\ ${ }^{1}$ Norwegian University of Science and Technology, 7491 Trondheim, Norway \\ ${ }^{2}$ NGU, Geological Survey of Norway, 7491 Trondheim, Norway \\ * now at: Institute of Geology, Mineralogy \& Geophysics, Ruhr University, Bochum, Germany
}

Received: 15 February 2011 - Published in Solid Earth Discuss.: 25 February 2011

Revised: 9 June 2011 - Accepted: 13 June 2011 - Published: 11 July 2011

\begin{abstract}
The Møre-Trøndelag Fault Complex (MTFC) has controlled the tectonic evolution of Mid Norway and its shelf for the past $400 \mathrm{Myr}$ through repeated reactivations during Palaeozoic, Mesozoic and perhaps Cenozoic times, the very last phase of reactivation involving normal to oblique-slip faulting. Despite its pronounced signature in the landscape, its deep structure has largely remained unresolved until now. We focused on two specific segments of the MTFC (i.e. the Tjellefonna and Bæverdalen faults) and acquired multiple geophysical datasets (i.e. gravity, magnetic, resistivity and shallow refraction profiles).

A $100-200 \mathrm{~m}$-wide zone of gouge and/or brecciated bedrock steeply dipping to the south is interpreted as being the Tjellefonna fault sensu stricto. The fault appears to be flanked by two additional but minor damage zones. A secondary normal fault also steeply dipping to the south but involving indurated breccias was detected $\sim 1 \mathrm{~km}$ farther north. The Bæverdalen fault, $\sim 12 \mathrm{~km}$ farther north, is interpreted as a $\sim 700 \mathrm{~m}$-wide and highly deformed zone involving fault gouge, breccias and lenses of intact bedrock. As such, it is probably the most important fault segment in the studied area and accommodated most of the strain during presumably Late Jurassic normal faulting. Our geophysical data are indicative of a Bæverdalen fault dipping steeply towards the south, in agreement with the average orientation of the local tectonic grain. Our findings suggest that the influence of Mesozoic normal faulting along the MTFC on landscape development is more complex than previously thought.
\end{abstract}

Correspondence to: A. Nasuti (aziz.nasuti@ngu.no)

\section{Introduction}

The Møre-Trøndelag Fault Complex (MTFC, Fig. 1), Mid Norway, is a long-lived structural zone whose tectonic history has involved repeated reactivation since Caledonian times (e.g. Grønlie et al., 1994; Watts 2001). The MTFC appears to have controlled the evolution of both the oil-rich basins offshore (Brekke, 2000) and the rugged landscape onshore (Redfield et al., 2005). It strikes ENE-WSW, paralleling the coastline of Mid Norway southwest of Trondheimsfjord, and separates the northern North Sea basin system from the deep Mesozoic Møre Basin (Brekke, 2000). Despite its pronounced signature in the landscape, its deep structure has largely remained unresolved until now, the only exception being the interpretation of a seismic reflection profile on Fosen Peninsula (Hurich and Roberts, 1997). The fault cores themselves are, in general, not exposed and their respective traces can only be seen as topographic lineaments (Fig. 1). Furthermore, their exact locations, extents, widths and dips remain, with the exception of the Hitra-Snåsa and Verran faults on Fosen Peninsula (e.g. Grønlie and Roberts, 1989), in most cases speculative and have not been studied systematically by means of geophysical methods.

A common assumption behind most geological models proposed to describe the regional tectonic evolution is that the ENE-WSW faults of the MTFC dip, in general, steeply towards the north-northwest and, therefore, represent the inland boundaries of the offshore basins (e.g. Gabrielsen et al., 1999). Redfield et al. (2005) proposed, in particular, that the abrupt change in elevation seen just southeast of the MTFC, with higher topography in the south, reflects Mesozoic normal faulting to the north-northwest along the major segments of the fault complex. Furthermore, according

Published by Copernicus Publications on behalf of the European Geosciences Union. 


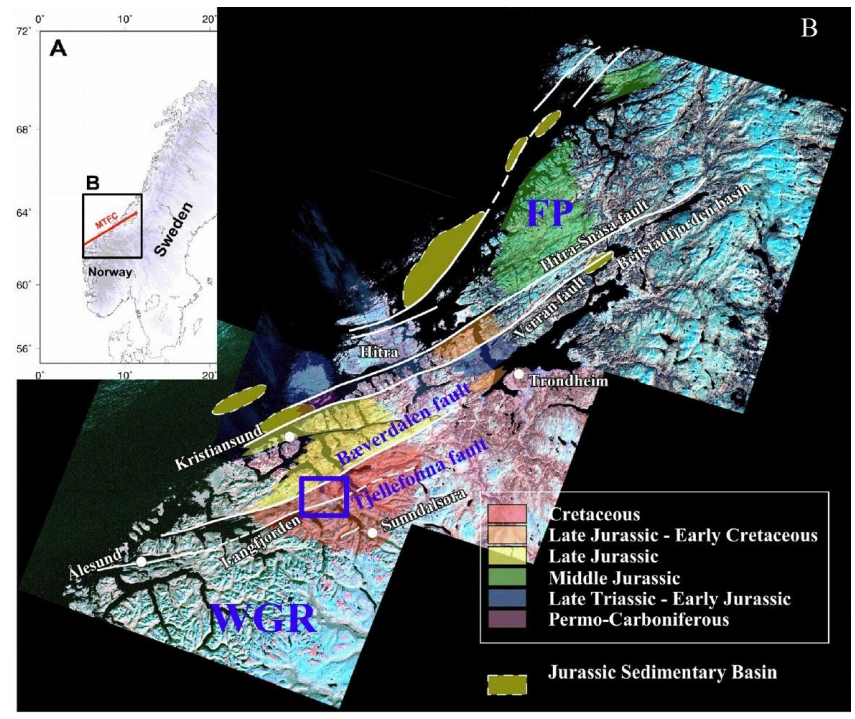

Fig. 1. Principal structural features of the Møre-Trøndelag Fault Complex (MTFC) and surrounding regions. (A) Location of the Mre-Trndelag Fault Complex (MTFC) onshore Norway. (B) Composition of three LandSat scenes showing the major lineaments of the MTFC (after Redfield et al., 2005). The blue frame depicts the study area. FP- Fosen Peninsula, WGR- Western Gneiss Region.

to this latter model, the present-day topography of southern Norway (i.e. the Southern Scandes) would have been the result of this last phase of reactivation of the MTFC. A consensus on the origin of the enigmatic topography of Norway is, however, still pending (e.g. Nielsen et al., 2009; Gabrielsen et al., 2010). With the present study, we aim to shed new light on the deep structure of the MTFC and introduce new observations and data to the ongoing debate. We present the results of the acquisition of several geophysical datasets across two of the major segments of the MTFC, the so-called Tjellefonna and Bæverdalen faults (Fig. 1), and discuss their significance in terms of the geological evolution of the area.

\section{Geology and tectonic setting of the study area}

The study area is located in the Western Gneiss Region (WGR) of Mid Norway (Fig. 1). Regional-scale interpretations (Gabrielsen and Ramberg, 1979; Nasuti et al., 2010b) indicate that two segments of the MTFC (i.e. the Bæverdalen and Tjellefonna faults, informally named by Redfield et al., 2004 and Redfield and Osmundsen, 2009, respectively) cross the study area. The WGR is a basement window exhumed in Devonian to Early Carboniferous times as part of a megascale, late- to post-Caledonian extensional or transtensional system (e.g. Andersen and Jamtveit, 1990; Krabbendam and Dewey, 1999; Braathen et al., 2000). The bedrock of the area is dominated by Late Palaeoproterozoic gneisses strongly reworked during the Caledonian Orogeny (Tveten

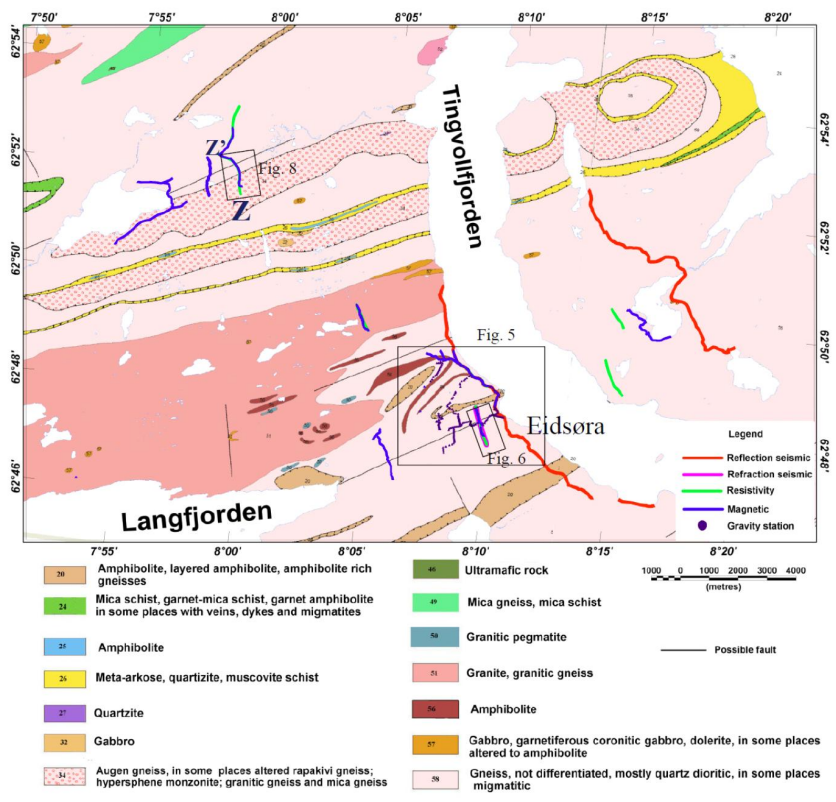

Fig. 2. Simplified bedrock map of the study area (after Tveten et al., 1998). The respective locations of the different geophysical profiles are shown. The black boxes outline some of the geophysical profiles shown in Figs. 5, 6 and 8.

et al., 1998). The gneisses have a magmatic origin and are locally migmatitic, varying from quartz-dioritic to granitic compositions (Fig. 2).

The structural grain inherited from the Caledonian event consists of polyphase tight to open folds with axes trending ENE-WSW (e.g. Tucker et al., 1990; Robinson, 1995; Hacker et al., 2010). Field evidence shows that the steep flanks of the folds were subsequently exploited to accommodate sinistral strike-slip in Devonian (Grønlie et al., 1991; Séranne, 1992; Watts, 2001) and normal dip-slip faulting in post-Mid Jurassic times (i.e. presumably Late Jurassic-Early Cretaceous, Bøe and Bjerkli, 1989; Bering, 1992; Grønlie et al., 1994). Reactivations of the MTFC in Permo-Triassic (Grønlie et al., 1994) and Cenozoic time (Grønlie et al., 1990; Redfield et al., 2005) have been proposed but firm evidence to support these latter faulting events is still lacking. The MTFC is moderately active at the present-day and appears to divert the regional stress field (Pascal and Gabrielsen, 2001; Roberts and Myrvang, 2004; Pascal et al., 2010).

Interestingly, Redfield et al. (2004, 2005) and Redfield and Osmundsen (2009) report significant apatite fission track (AFT) age jumps across the major ENE-WSW segments of the MTFC (Fig. 1), most apparent ages ranging from Triassic to Early Cretaceous. This group of authors explain the general trend of a southward decrease in AFT ages with a model involving gradual erosion of the uplifted successive footwalls, faulting and erosion progressing away from the rifted 


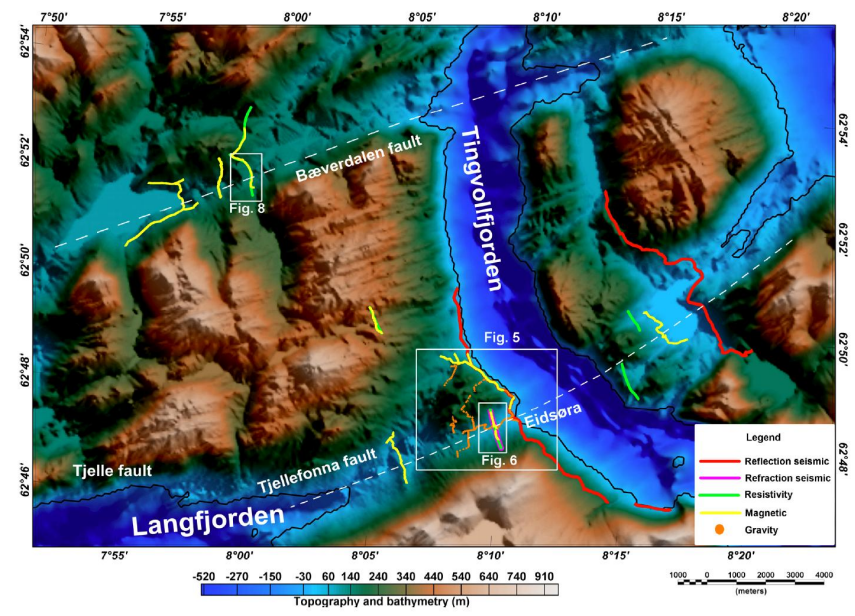

Fig. 3. Several geophysical datasets have been acquired in the study area (blue box in Fig. (1). The background map depicts topography and bathymetry. The white boxes outline geophysical profiles whose corresponding results are shown in Figs. 5, 6 and 8. Dashed white lines show the proposed Tjellefonna and Bverdalen faults.

margin from north to south (i.e. the "scarp retreat" model). Accordingly, the abrupt relief south of the Tjellefonna fault (Fig. 1) and, in general, the topography of southern Norway would be relics of this process. An implication of the "scarp retreat" model is that faults of the MTFC should dip towards the north.

\section{Data acquisition}

In order to detect the fault zones and their structural attributes, a series of gravity, magnetic, 2-D-resistivity, shallow-refraction and reflection-seismic profiles were measured across two presumed segments (Figs. 2 and 3) as part of the MTFC Integrated Project (Nasuti et al., 2009, 2010a). Note that a detailed description and interpretation of the reflection seismic profiles will be presented in a forthcoming publication, so far reported only in an abstract (Lundberg et al., 2009). Gravity and magnetic data help to determine the thickness of the overburden and eventually the location of the fault cores. In addition, rock sampling and petrophysical measurements on densities and magnetic susceptibilities in the study area constrain the geophysical models. 2-Dresistivity and shallow-refraction seismic data are commonly used to map fractures and faults. Resistivity studies image shallow/near-surface structures with higher resolution than seismic surveys. Along one of the 2-D resistivity profiles, shallow-refraction seismic data were also acquired. Refraction seismics is generally very effective at determining heavily fractured bedrock and wide zones of fault gouge.

\subsection{Gravity data}

In total, 265 gravity stations were established in a $4 \times 4 \mathrm{~km}$ area close to Eidsøra (Fig. 3). The gravity survey was planned to study the thickness of the overburden and to detect eventual gravity signals related to the faults. The distance between gravity stations varied from 15 to $80 \mathrm{~m}$. More densely spaced gravity data were acquired in the vicinity of the Tjellefonna fault, in particular along profiles perpendicular to the strike of the inferred fault. Away from it, station spacing was increased. For all stations the elevation was determined by levelling. In order to increase the accuracy of our survey, measurements were carried out at least twice at each gravity station. For positioning we used a total station survey camera with a precision of $1 \mathrm{~mm}$. Measuring accuracy was in the order of 10 to $20 \mu \mathrm{Gal}$. A combined bathymetrytopography compilation (Olesen et al., 2010) with a resolution of $(250 \times 250 \mathrm{~m})$ was used for the regional terrain correction, and a high-resolution grid $25 \times 25 \mathrm{~m}$ created by the Norwegian Mapping Authority, based on triangulation of $20 \mathrm{~m}$ contour maps and road and river data, was used over the study area. Further details about data acquisition can be found in Nasuti et al. (2010a).

\subsection{Magnetic data}

The magnetic profiles were set up in order to cross the two chosen segments of the MTFC. Fifteen magnetic profiles with variable lengths from 1000 to $2500 \mathrm{~m}$ were measured (Fig. 3). Measurements were made using a GSM-19 magnetometer with two sensors separated vertically by $56 \mathrm{~cm}$ in order to measure vertical gradients and the total magnetic field simultaneously.

A significant number of noise sources (e.g. power lines, electric fences) exist in the survey area and, consequently, high noise levels were recorded along some of the profiles (Nasuti et al., 2010a). Such high-amplitude noise overprints the anomalies related to geological structures and had to be removed before processing. A $50 \mathrm{~Hz}$ low-pass filter was used to remove noise and very high frequencies. Measured vertical gradients are in most cases affected by high noise levels; therefore, we focused only on total magnetic field anomalies. The magnetic data were further corrected for diurnal variations using base station readings and the International Geomagnetic Reference Field 2005 was subtracted.

\subsection{Petrophysical data and Bouguer corrections}

Magnetic and gravity properties were derived from petrophysical measurements made on rock samples collected, in the framework of the project, in secondary fault zones and their host rocks (Biedermann, 2010). The samples consist mainly of gneisses and amphibolites typical of the area (Fig. 2). Samples A to L were collected along a profile following the southwestern shore of Tingvollfjorden (Fig. 5). 

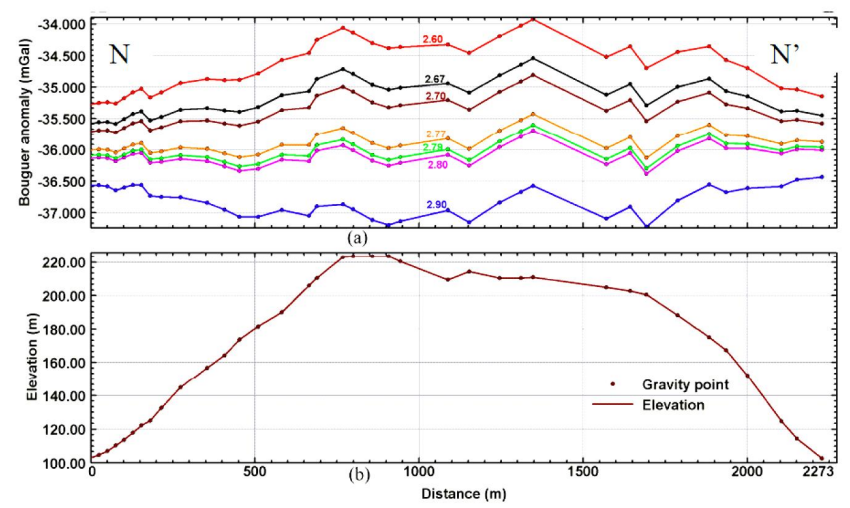

Fig. 4. Determination of the bulk density of the studied domain using the Nettleton Method. (a) Computed Bouguer anomalies along NN using different densities. The location of this profile is shown in Fig. 5. (b) Topography of the profile with location of the gravity points.

Samples F, G and H originated from locations just north and south of the surface expression of a minor but visible fault. Analysis of the samples showed that the bulk magnetic susceptibility of the gneisses varies from $\sim 10^{-4}$ to $\sim 10^{-2}$ SI (Table 1). The variation in bulk susceptibility over two orders of magnitude can be explained by changes in mineralogy, different concentrations of ferromagnetic minerals and varying grain sizes (see details in Biedermann, 2010).

Rock densities can be determined by measuring samples collected in the field. However, densities usually vary over a wide range even within the same rock unit, so that a large number of samples is required to determine a reliable average value. In addition, it is often difficult to obtain representative samples from well below the weathered surface. We applied the classical Nettleton method (Nettleton, 1939) to estimate the bulk density of the rocks in the gravity survey area and to compute Bouguer corrections.

The optimum density is estimated by calculating a series of Bouguer anomalies as a function of rock density and comparing with topography (Fig. 4). For the optimum density (i.e. the actual bulk density), the computed gravity anomaly profile should show minimal correlation with topography. It is essential that the topographic feature selected for the gravity profile displays at least one reversal (Fig. 4b, Nettleton, 1939). The optimum density was found to be $2790 \mathrm{~kg} \mathrm{~m}^{-3}$ along the traverse $\mathrm{N}-\mathrm{N}^{\prime}$. When compared to the measured densities (Table 1), this value falls between the typical values obtained for gneisses and amphibolites, suggesting that the rocks below the gravity profile are a mixture of both rock types.

Figure 5 shows Bouguer anomalies computed according to the optimum density value. Bouguer anomalies are quite modest (Fig. 5). A Bouguer low is, nevertheless, observed along the valley floor where the Tjellefonna fault is suspected to occur. However, this may reflect at the first order the
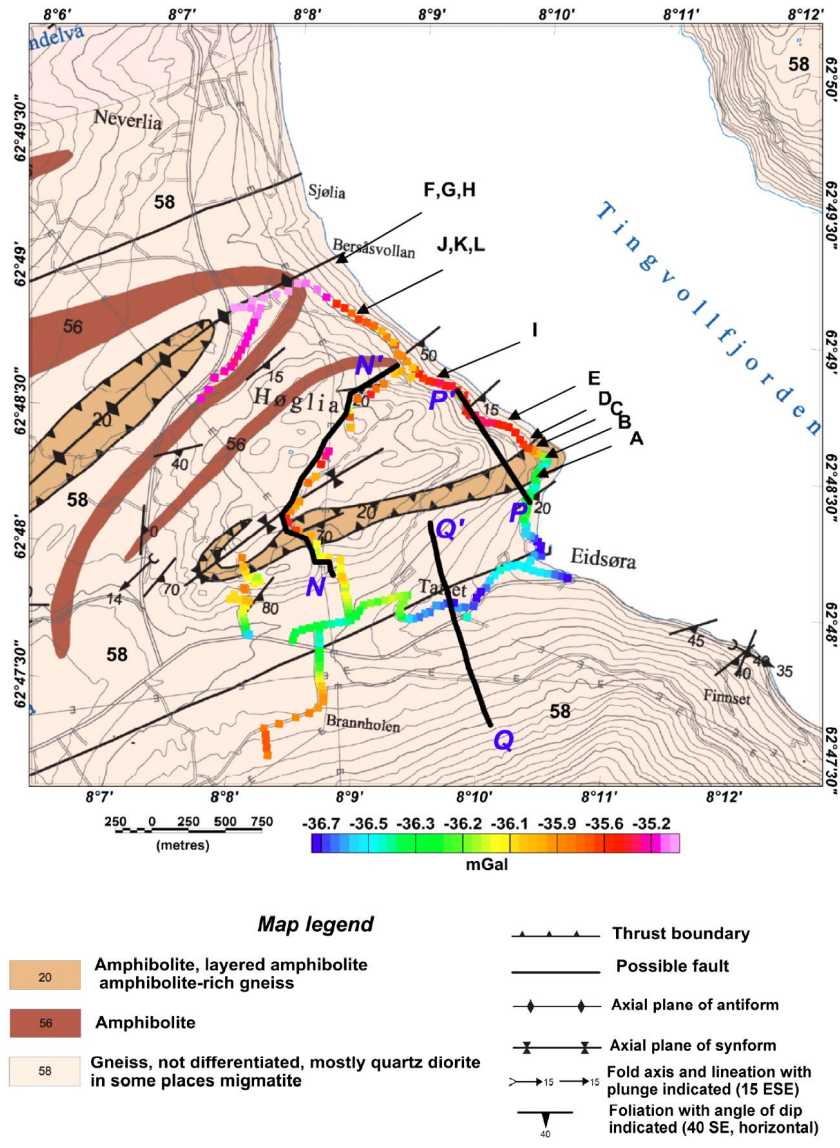

Fig. 5. Bouguer anomalies calculated using a reduction density of $2790 \mathrm{~kg} \mathrm{~m}^{-3}$ and superposed on the geological map (Tveten et al., 1998). $\mathrm{NN}^{\prime}$ is the traverse used to determine the reduction density (Fig. 4). $\mathrm{PP}^{\prime}$ and $\mathrm{kg} \mathrm{m}^{-3}$ are profiles shown in Figs. 7 and 8 respectively. Letters in black represent petrophysical sampling sites (Biedermann, 2010).

low-density Quaternary overburden, which varies in thickness from a few metres to several tens of metres. We will address this issue further below.

\subsection{Resistivity}

The 2-D-resistivity survey consists of seven profiles, mostly oriented NW-SE in order to cross the fault structures perpendicularly (Figs. 2 and 3). The resistivity method measures apparent resistivity in the subsurface, which is a weighted average of all resistivity values within the measured volume (Dahlin, 1996, Reynolds, 1997). The 2-D-resistivity profiles were acquired according to the Lund system (Dahlin, 1996). Data were collected with a gradient array configuration with electrode spacing of 10 and $20 \mathrm{~m}$ to map the shallow and deeper parts of the profiles respectively. The depth penetration is approximately $130 \mathrm{~m}$, with a reliable data coverage to approximately $70 \mathrm{~m}$ depth. 
Table 1. Summary of the physical properties of the rock samples. Details of the petrophysical analysis and sample information are given in Biedermann (2010).

\begin{tabular}{lccc}
\hline Lithology & Density range $\left(\mathrm{kg} / \mathrm{m}^{3}\right)$ & Susceptibility range $(\mathrm{SI})$ & Number of samples \\
\hline Gneisses & $2643-2745$ & $9.92 \times 10^{-5}-1.21 \times 10^{-2}$ & 10 \\
& Median: 2680 & Median: $2.23 \times 10^{-3}$ & \\
Amphibolites & $2938-3066$ & $7.46 \times 10^{-4}-1.28 \times 10^{-3}$ & 2 \\
& Mean: 3002 & Mean: $1.02 \times 10^{-3}$ & \\
Fault rocks & $2504-2642$ & $1.13 \times 10^{-3}-1.19 \times 10^{-2}$ & 4 \\
& Median: 2623 & Median: $4 \times 10^{-3}$ & \\
\hline
\end{tabular}

Measured apparent resistivities with different electrode configurations were converted into 2-D true resistivity profiles using the Res2-Dinv software (Loke, 2004). In the inverted profiles, relatively low-resistive zones may indicate fractured and/or water saturated bedrock, while more resistive ones are diagnostic for fresh bedrock. Particularly low resistivity (i.e. lower than $1000 \Omega \mathrm{m}$ ) characterises clay-filled fractures and, consequently, also fault gouge (e.g. Ganerød et al., 2008). Further details can be found in Nasuti et al. (2009).

\subsection{Seismic profiling}

Two reflection and one shallow-refraction seismic profiles were acquired perpendicular to the Tjellefonna fault (Fig. 3). The reflection-seismic profiles were shot on both sides of Tingvollfjorden with the aim of imaging the upper $4 \mathrm{~km}$ of the crust. Details on this particular study will soon be published by Lundberg and Juhlin (2011). The refraction profile was $1320 \mathrm{~m}$ long (Fig. 3). The profile was measured with two seismic cables, each involving 12 geophone connections. Geophone spacing along the cables was $10 \mathrm{~m}$, except at the end of the cables where the spacing was reduced to $5 \mathrm{~m}$. Along each cable, five shots were arranged with $110 \mathrm{~m}$ shot spacing in each layout. For short distances 100 grams of dynamite were used, while up to 200 grams were used for greater distances from the geophones. The classical plusminus method (Hagedoorn, 1959) was used for estimating seismic velocities and layer thickness in combination with estimating layering and thickness from intercept times and crossover distances. The interpretation is shown in Fig. 6a. More details can be found in Nasuti et al. (2009).

\section{Integration and interpretation of the geophysical data}

\subsection{Tjellefonna fault}

Figure 6 shows the results from three independent datasets acquired across the Tjellefonna fault along profile $\mathrm{QQ}^{\prime}$ (Fig. 5). At the top, a thin layer of soil with very low seismic $\mathrm{P}$-wave velocities (400-600 $\mathrm{m} \mathrm{s}^{-1}$ ) is imaged. Just below this layer, P-wave velocities increase to $1400-2300 \mathrm{~m} \mathrm{~s}^{-1}$ in what

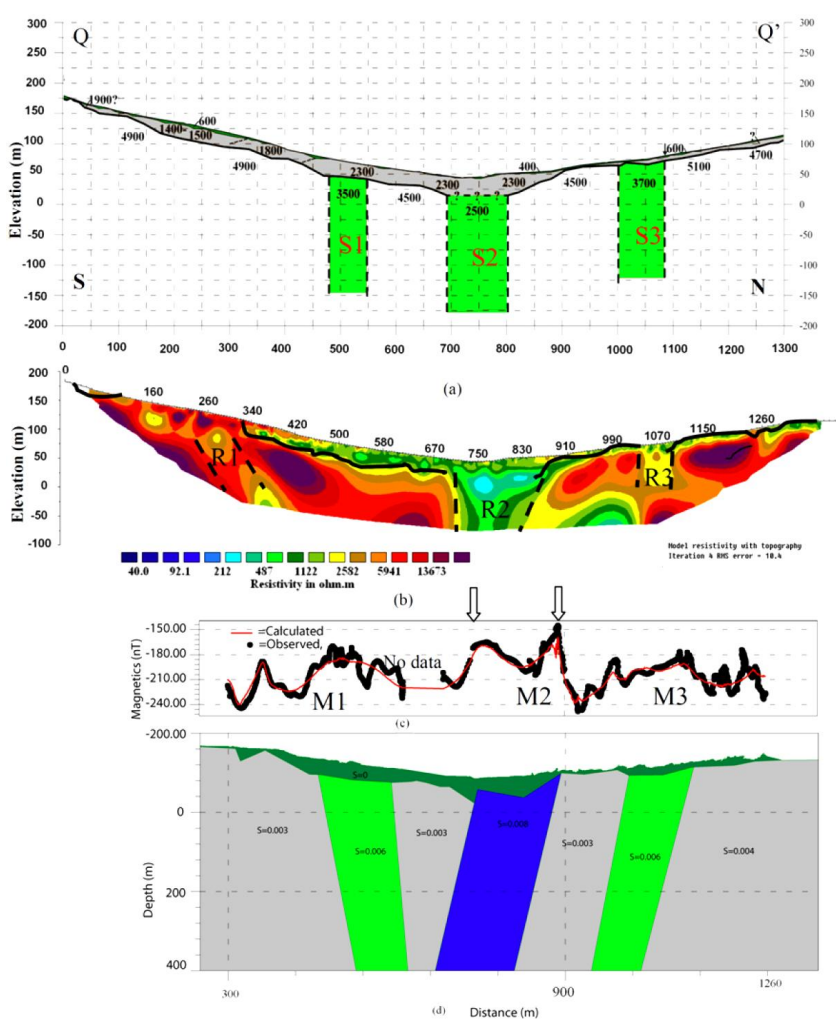

Fig. 6. Geophysical profiling across the Tjellefonna Fault. (a) The refractionseismic profile shows three low-velocity zones (S1, S2 and S3); velocities in $\mathrm{m} \mathrm{s}^{-1}$. (b) Depth-inverted 2-D-resistivity profile showing three low-resistivity zones (R1, R2 and R3). Continuous and dashed lines represent the interpreted top bedrock and the edges of the interpreted main fault zone, respectively. (c) Magnetic profile. The arrows on top of the magnetic anomaly show the edges of the interpreted main fault zone. Profile locations are shown in Figs. 3 and 5. (d) A model is proposed for magnetic anomalies.

is interpreted to be the Quaternary overburden. The underlying bedrock has, in general, velocities of $4500-5100 \mathrm{~m} \mathrm{~s}^{-1}$, but clearly shows three distinctive, vertical, low-velocity zones (Fig. 6a). Low P-wave velocity values (i.e. less than $4000 \mathrm{~m} \mathrm{~s}^{-1}$ ) suggest the presence of densely fractured and/or fault gouge. We note that S2 appears to be wider than S1 
and S3. Furthermore, S2 is associated with a lower velocity (i.e. $2500 \mathrm{~m} \mathrm{~s}^{-1}$ ) with respect to the two other velocity anomalies (i.e. 3500 and $3700 \mathrm{~m} \mathrm{~s}^{-1}$ for $\mathrm{S} 1$ and S3, respectively). These observations are suggestive of highly strained rock material and, presumably, the presence of significant volumes of densely fractured and/or unconsolidated fault gouge at the location of S2.

We imaged a low-resistive top layer (Fig. 6b) corresponding to the top low-velocity layer (Fig. 6a) and representing, without doubt, the unconsolidated Quaternary sediments. Low-resistive anomalies are also imaged in the bedrock (i.e. R1, R2 and R3, Fig. 6b). The length of the resistivity profile, acquired following the refraction seismic line, is $1400 \mathrm{~m}$. A remarkably good spatial correlation is found between seismic anomaly S2 and R2 and between S3 and $\mathrm{R} 3$, adding support to the interpretation that these co-located anomalies represent fault zones. In particular, the respective widths of S2 and R2 are very similar. The southern edge of R2 looks vertical but we note that the apparent geometry of its northern edge strongly suggests a structure dipping towards the south. No visible counterpart is found for seismic anomaly S1. This latter seismic anomaly may potentially be a blind zone created by shallow cavities (Westerdahl, 2003) and, therefore, may not represent any actual fault zone. In turn, R1 might represent a relatively minor deformation zone.

In order to refine our interpretation, we compare the previous results with our magnetic data. Because of the presence of a high-voltage power line, the magnetic profile contains a small gap of $\sim 100 \mathrm{~m}$. Nevertheless, three magnetic anomalies depicted as central lows between high-amplitude and mainly short-wavelength peaks can be distiguished (i.e. M1, M2 and M3, Fig. 6c). M2 is the most pronounced magnetic anomaly and correlates very well with seismic anomaly S2 and resistivity anomaly R2. Contacts between rocks with contrasting magnetic properties are commonly associated with positive and negative magnetic anomalies with steep gradients. The M2 anomaly appears to reflect the existence of two rock contacts in the subsurface correlating with the edges of R2 and that we interpret as the two outer boundaries of the fault zone (Fig. 6c). In brief, the analysis of the three geophysical datasets points unambiguously to the presence of a 100-200 m-wide fault zone at the centre of profile $\mathrm{kg} \mathrm{m}^{-3}$ that we interpret as the Tjellefonna fault sensu stricto. Magnetic anomaly M3 appears to be less pronounced but it may be related to both seismic anomaly S3 and resistivity anomaly R3. Our interpretation is that a secondary and narrower fault produces these signals, including perhaps M3. Finally, some correlation appears between magnetic anomaly M1 and seismic anomaly S1, and both geophysical anomalies are tentatively attributed to another minor fault zone; however, as discussed previously, this latter interpretation remains uncertain. A forward model was run to further evaluate the magnetic anomalies (Fig. 6d). The model involves three zones with higher susceptibilities which could reflect fault zones enriched in magnetic minerals. M2 was reason-

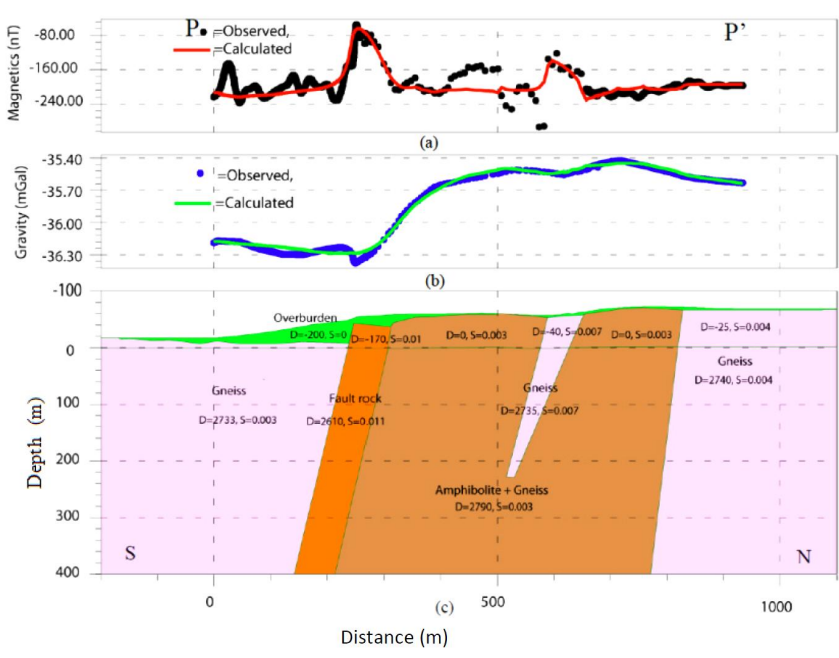

Fig. 7. 2-D model along profile $\mathrm{PP}^{\prime}$. Density $(D)$ and susceptibility $(S)$ of the blocks are in SI units. See text for modelling details. Note that for modelling Bouguer gravity anomalies, density contrasts with respect to the reduction density are used above the reduction level (i.e. sea-level).

ably well simulated by a southward-dipping zone, which we propose corresponds to the major fault zone of the area. The overburden thickness was calibrated according to the seismic and resitivity data.

\subsection{A subordinate fault to the Tjellefonna fault}

We now focus on profile $\mathrm{PP}^{\prime}$ that we anticipated to cross a secondary structure adjacent to the Tjellefonna fault (Fig. 5). The Bouguer anomaly displays a steep gradient (Figs. 5 and 7). This gradient is expressed by a step-like anomaly with an amplitude of $0.8 \mathrm{mGal}$ coinciding with a pronounced positive anomaly in the magnetic data (Fig. 7a). We used the GMSYS-2-D modelling package (Popowski et al., 2009) in order to model the sources of the observed Bouguer and magnetic anomalies along profile $\mathrm{PP}^{\prime}$.

The physical parameters (i.e. density and magnetic susceptibility) used to model the host rocks are based on laboratory measurements of samples collected along profile PP' (Biedermann, 2010) and summarised in Table 1. Biedermann's study indicates that the magnetic anomalies are dominated by induced magnetisation. Therefore, the effect of remanent magnetisation can be neglected in the modelling. The measured density values for each type of rock show a relatively wide scatter and we used these ranges of values to constrain the most likely densities in the model. We rely on the density determined by means of the Nettleton method (i.e. $2790 \mathrm{~kg} \mathrm{~m}^{-3}$, Fig. 4) for the central part of the $\mathrm{PP}^{\prime}$ profile that involves a mixture of amphibolites and gneisses. Note that the bedrock map (Fig. 5) indicates a narrower strip of amphibolites as compared to our 2-D model (Fig. 7). However, we observed and sampled amphibolites outside the area 
where they have been reported (i.e. samples F and J, Fig. 5 and Biedermann, 2010), supporting the suggestion that the central part of our profile involves a mixture of both rock types.

A southward-dipping block with a density of $2610 \mathrm{~kg} \mathrm{~m}^{-3}$ and a magnetic susceptibility of 0.011 (SI units) is added to the model to simulate fault rocks. The chosen values for the modelling were calibrated according to the results of the petrophysical measurements carried out on five fault rock samples (Biedermann, 2010, Table 1). These samples consist of indurated breccias and were collected a few kilometres east and west of Eidsøra but along the same topographic lineament as the one crossing the study area (see precise locations in Biedermann, 2010). Note that our choice of a fault dipping to the south in the model is supported by (1) the average dip of the local structural grain as measured in the field (i.e. foliation, Fig. 5) and (2) reflection-seismic experiments showing a reflector presumably related to the fault dipping $60-70^{\circ}$ to the south (Lundberg et al., 2009). After testing various modelling scenarios, we concluded that one realistic solution to explain the observed gravity and magnetic fields is that a $\sim 50 \mathrm{~m}$-wide and south-dipping fault zone composed of indurated breccias, like the ones cropping out near Tjelle (Redfield and Osmundsen, 2009; Bauck, 2010), separates mostly dioritic gneisses from a mixture of amphibolites and gneisses.

\subsection{Bæverdalen fault}

Figure 8 shows 2-D-resistivity and magnetic profiles measured perpendicular to the Bæverdalen fault. The inverted resistivity data show three low-resistive anomalies and a shallow layer with very low resistivity at the top of the section, corresponding to water-saturated sediments. The lowresistivity anomalies (A1, A2 and A3) along the profile may relate to highly strained zones of the MTFC and are interpreted to represent water-saturated, fractured and/or extensive fault gouge. There is a good spatial correlation between resistivity anomaly A1 and magnetic anomaly $\mathrm{U}$ (Fig. 8b). Anomaly $\mathrm{U}$ has an amplitude of $200 \mathrm{nT}$ and mimics the expected shape for a magnetic anomaly arising from a contact between two blocks with contrasting magnetic properties. However, the correlation between rock contacts imaged in the resistivity profile and that inferred from the magnetic one is not straightforward in the present case. Nevertheless, the structure of the subsurface below the location of magnetic anomaly $U$ appears to be complex, and the shape of anomaly A1 is suggestive of either a southward shallowdipping fault zone or (our preferred interpretation) a steep and wide crushed zone involving lenses of intact bedrock.

A high-resistivity anomaly is detected at the northern end of the profile, which points to intact bedrock and could eventually represent the moderately deformed footwall of the Bæverdalen fault. The shape of the anomaly suggests a steep rock contact, presumably the northern boundary of the dam-

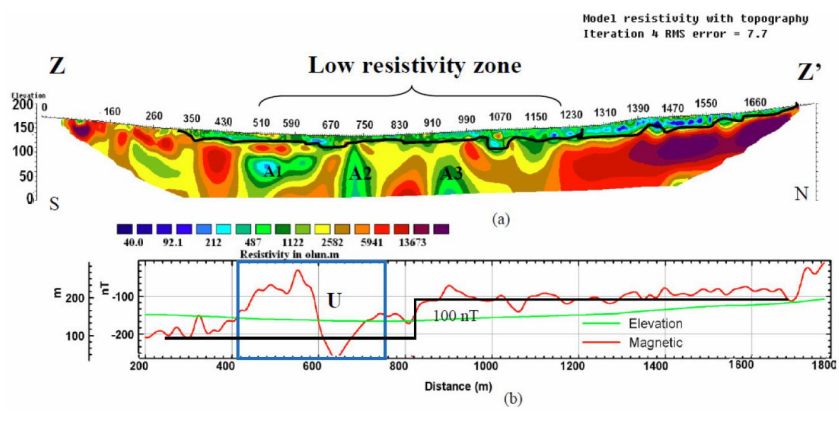

Fig. 8. Results from resistivity and magnetic profiling over the Bverdalen fault. (a) Results from inversion of the 2-D-resistivity data. (b) Magnetic profile (see Fig. 2 for location).

age zone. In general, resistivity is low to very low over a $\sim 700 \mathrm{~m}$-wide zone (Fig. 8a), suggesting a large faulted corridor. Furthermore, the magnetic trend along the profile shows a marked jump from $-200 \mathrm{nT}$ in the south to $-100 \mathrm{nT}$ in the north while crossing the low-resistive zone, suggesting different rocks or, at least, variations in petrophysical properties within the same rock unit separated by the inferred faulted corridor.

\section{Discussion}

The locations of the previously proposed Bæverdalen and Tjellefonna faults (e.g. Gabrielsen and Ramberg, 1979; Bryhni et al., 1990; Redfield et al., 2004; Redfield and Osmundsen, 2009) are confirmed by our integrated geophysical study (Figs. 6 and 7). The Tjellefonna fault system comprises a master fault (i.e. the Tjellefonna fault sensu stricto depicted by anomalies S2, R2 and M2 in Fig. 6), surrounded by two (?) damage zones in the centre of the valley of Eidsøra (Fig. 7) and a secondary fault less than $1 \mathrm{~km}$ farther north (Fig. 8). Our dataset suggests that the core of the master fault is $\sim 100-200 \mathrm{~m}$ wide and filled with water and/or clay minerals, hence presumably highly fractured and fault gouge rocks. As such, the structure of the core of the Tjellefonna fault appears to be similar to that of the Mulvik fault which is exposed $\sim 10 \mathrm{~km}$ northeast of Eidsøra (Bauck, 2010). From a quick glance at the topographic map, it can be seen that the two faults are not aligned and that the latter fault is probably a secondary structure of the former. Our geophysical measurements suggest a different nature for the secondary fault found farther north (Fig. 7). We interpret the observed high-magnetic signal and the gravity low to be associated with a fault core bearing similar petrophysical properties (i.e. high-magnetic susceptibility and low density, Table 1) to the indurated fault rocks from Tjelle and Mulvik (Biedermann, 2010). If our interpretation is correct, a field analogue for this fault could be the Tjelle fault (Redfield and Osmundsen, 2009). The Tjelle fault exposes mainly consolidated zeolite-rich breccias where the gneissic protolith is 
still evident and is interpreted to be a secondary structure of the Tjellefonna fault (Redfield and Osmundsen, 2009). The width of our modelled fault zone (i.e. $\sim 30 \mathrm{~m}$ ) appears to exceed by one order of magnitude the width of individual fault zones mapped at the outcrop scale near Tjelle (Redfield and Osmundsen, 2009; Bauck, 2010). In detail, the fault zone that we modelled most probably involves alternating 1 to $10 \mathrm{~m}$-wide fault zones and intact rock as observed in the field by Bauck (2010).

Our 2-D model (Fig. 7) suggests that the secondary fault dips steeply towards the south. Admittedly, we can only indicate the dip in the uppermost few hundred metres. However, our observations are in good agreement with both field observations on the Tjelle fault (Redfield and Osmundsen, 2009) and seismic-reflection data (Lundberg et al., 2009), which increases confidence in our findings. An obvious difference between the Tjelle fault and our secondary fault is that the former reactivated foliation planes flanking an antiform (Fig. 5 in Redfield and Osmundsen, 2009), whilst the latter apparently reactivated foliation flanking a synform (Fig. 5). The dip of the main fault of the Tjellefonna fault system can only be inferred from our resistivity data (Fig. 6b). Inversion of the data suggests that the northern edge of the fault core (i.e. R2 in Fig. 6b) is dipping steeply towards the south while the southern edge is subvertical. We carried out sensitivity tests by means of forward modelling and changing the dip directions of both edges. The geometry shown in Fig. $6 \mathrm{~b}$ is the most elegant one in terms of reproducing the results of our resistivity inversion. Considering that the metamorphic foliation, both at the regional and local scales, dips in general towards the south (Bryhni et al., 1990, Fig. 5) and that, without any exception, the faults of the MTFC whose internal architecture is exposed have been shown to reactivate the preexisting structural grain (Grønlie et al., 1991; Séranne, 1992; Watts, 2001; Redfield and Osmundsen, 2009; Bauck, 2010), we feel that our interpretation of a south-dipping Tjellefonna fault is geologically sound.

The geophysical experiments suggest that the Bæverdalen fault is characterised by a wide corridor of deformation (i.e. $\sim 700 \mathrm{~m}$, Fig. 8 ) containing alternating $\sim 50-100 \mathrm{~m}$-wide zones of fault gouge, highly fractured (i.e. permeable) rock and relatively intact bedrock. This relatively wide deformation corridor points to significant displacements along the Bæverdalen fault (e.g. Scholtz, 2002). The Bæverdalen fault is also associated with (1) a pronounced jump in apatite fission track ages (Redfield et al., 2004) and (2) marked gravity and magnetic gradients (Skilbrei et al., 2002; Nasuti et al., 2010b), adding support to the idea that it is one of the master faults of the MTFC. Note that when crossing the Bæverdalen fault, the regional magnetic gradient is visible in our ground data as a step of $\sim 100 \mathrm{nT}$ (Fig. 8b). The deformation corridor related to the Bæverdalen fault reaches its northernmost extension at horizontal coordinate 1200 on profile $\mathrm{ZZ}^{\prime}$ (Fig. 8), where highly resistive bedrock is encountered. An additional resistivity profile, acquired $\sim 200 \mathrm{~m}$ farther north, confirms that the bedrock remains highly resistive, hence presumably intact, for at least a distance of $2 \mathrm{~km}$ from this specific location. In general and because they are prone to severe rotations, the hanging-walls of normal faults tend to be much more fractured than their footwalls (e.g. Fossen and Gabrielsen, 1996; Berg and Skar, 2005). Consequently, we interpret the highly resistive bedrock observed north of the Bæverdalen fault as being its footwall. A corollary of our interpretation is that the Bæverdalen fault dips to the south, in agreement with the local tectonic grain (Bryhni et al., 1990). Admittedly, this latter conclusion remains more uncertain than in the case of the Tjellefonna fault.

Our findings have implications for the ongoing debate on the origin of the Scandinavian Mountains, also termed the Scandes (e.g. Nielsen et al., 2009, Pascal and Olesen, 2009; Gabrielsen et al., 2010). It has been proposed that the relief of Mid Norway reflects normal faulting along the major segments of the MTFC that occurred in the geological past (Redfield and Osmundsen, 2009 and references therein). The high-topography beginning south of Langfjorden (Fig. 3) is interpreted by these authors to be the uplifted footwall of the Tjellefonna fault. This hypothesis requires a northwarddipping Tjellefonna fault, which is in obvious contradiction to our findings. The "scarp retreat" model proposed by Redfied et al. (2005) relies on the interpretation of apatite fission track ages and, in particular, the abrupt age changes recorded when crossing the major lineaments of the MTFC. The recent publication by Redfield and Osmundsen (2009) of additional AFT ages shows a much more complex pattern, where significant age variations also occur parallel to the MTFC over relatively short distances (i.e. $\sim 50 \mathrm{~km}$ ). Although the "scarp retreat" model is still appealing, the new AFT data and our own observations call for further refinements to this model.

\section{Conclusions}

Several geophysical datasets (i.e. refraction seismic, resistivity, magnetics and gravimetrics) have been acquired in order to image the respective depth structures of two major segments of the MTFC, the Tjellefonna and Bæverdalen faults. The Tjellefonna fault sensu stricto is interpreted as a 100-200 m-wide zone of gouge and/or water-saturated, fractured bedrock dipping steeply to the south. This fault zone appears to be flanked by two additional but minor damage zones, but only one of them can be determined with sufficient confidence. A secondary normal fault also dipping steeply to the south but involving indurated breccias has been detected $\sim 1 \mathrm{~km}$ farther north. The Bæverdalen fault is interpreted as a $\sim 700 \mathrm{~m}$-wide and highly deformed zone involving fault gouge, densely fractured rocks and intact bedrock, embedded within the fault rock products, and as such, it is probably the most important fault segment in the studied area and accommodated most of the strain during inferred Late Jurassic normal faulting. Our geophysical data suggest 
that the Bæverdalen fault dips steeply towards the south, in agreement with the average orientation of the local tectonic grain. In summary, our geophysical observations suggest, in turn, that the influence of Mesozoic normal faulting along the MTFC on landscape development is more complex than previously thought.

Acknowledgements. We are particularly grateful to Gerald Gabriel and Hermann Zeyen for their thorough and insightful reviews. This project is a joint cooperation between the Geological Survey of Norway (NGU), Uppsala University and NTNU financed by the Norwegian Research Council (NFR-Frinat project 177524: "The Møre-Trøndelag Fault Complex - an integrated study”). We are thankful to Jomar Gellein and Einar Dalsegg for their assistance during fieldwork and data acquisition. We also want to thank all the students from ETH Zürich, NTNU, Uppsala, Trieste and Yaoundé Universities who helped us during data acquisition. Discussions with Emil Lundberg, Chris Juhlin, Andrea Biedermann, Tim Redfield, Jan Steinar Rønning and David Roberts are greatly appreciated. Roberts is particularly thanked for correcting the English text and improving the manuscript.

Edited by: J. C. Afonso

\section{References}

Andersen, T. B. and Jamtveit, B.: Uplift of deep crust during orogenic extensional collapse: a model based on field studies in the Sogn-Sunnfjord region, W. Norway, Tectonics, 9, 1097-1111, 1990.

Bauck, M. S.: Fault rock assemblages and fault architecture in

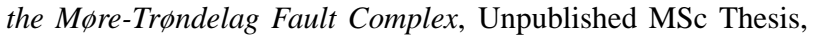
NTNU Trondheim, 2010.

Berg, S. S. and Skar, T.: Controls on damage zone asymmetry of a normal fault zone: outcrop analyses of a segment of the Moab fault, SE Utah, J. Struct. Geol., 27, 1803-1822, 2005.

Bering, D.: The orientation of minor fault plane striae and the associated deviatoric stress tensor as a key to the fault geometry in part of the Møre-Trøndelag fault zone, on-shore central Norway, in: Structural and Tectonic Modelling and its Application to Petroleum Geology, edited by: Larsen, R. M., Brekke, H., Larsen, B. T. and Talleraas, E., Norwegian Petroleum Society (NPF), Special Publications, 1, 83-90, 1992.

Biedermann, A. R.: Magnetic Properties of the More-Trøndelag Fault Complex, MSc Thesis, ETH Zürich, http://e-collection. library.ethz.ch/view/eth:1986, 2010.

Bøe, R. and Bjerkli, K.: Mesozoic sedimentary rocks in Edøyfjorden and Beitstadfjorden, Central Norway: Implications for the structural history of the Møre-Trøndelag fault zone, Mar. Geol., 87, 287-299, 1989.

Braathen, A., Nordgulen, Ø., Osmundsen, P. T., Andersen, T. B., Solli, A., and Roberts, D.: Devonian, orogen-parallel, opposed extension in the Central Norwegian Caledonides, Geology, 28, 615-618, 2000.

Brekke, H.: The tectonic evolution of the Norwegian Sea continental margin, with emphasis on the Vøring and Møre Basins, in: Dynamics of the Norwegian Margin, edited by: NØTTVEDT, A., Special Publication, Geol. Soc. Lond., 167, 327-378, 2000.
Bryhni, I., Austrheim, H., Bjørnstad, Kullerud, L., and Reksten, K.: Bergrunnskart Tingvoll, 13201 1:50000, Foreløpig utgave, Geological Survey of Norway, Trondheim, 1990.

Dahlin, T.: 2-D resistivity surveying for environmental and engineering applications, First Break, 14, 275-284, 1996.

Fossen, H. and Gabrielsen, R. H.: Experimental modelling of extensional fault systems by use of plaster, J. Struct. Geol., 18, 673$687,1996$.

Gabrielsen, R. H. and Ramberg I. B.: Fracture patterns in Norway from LANDSAT imagery: results and potential use, in: Proceedings of the Norwegian Sea Symposium, NSS/20, Troms $\emptyset$, NPF SP. Publ., 1-10, 1979.

Gabrielsen, R. H., Odinsen, T., and Grunnaleite, I.: Structuring of the Northern Viking Graben and the Møre Basin; the influence of basement structural grain, and the particular role of the Møre- Trøndelag Fault Complex, Mar. Petrol. Geol., 16, 443465, 1999.

Gabrielsen, R. H., Faleide, J. I., Pascal, C., Braathen, A., Nystuen, J.-P., Etzelmuller, B., and O'Donnell, S.: Latest Caledonian to Present tectonomorphological development of southern Norway, Mar. Petrol. Geol., 27, 709-723, 2010.

Ganerød, G. V., Grøneng, G., Rønning, J. S., Dalsegg, E., Elvebakk, H., Tønnesen, J. F., Kveldsvik, V., Eiken, T., Blikra, L. H., and Braathen, A.: Geological model of the Åknes rockslide, western Norway, Engeering Geology, 102(1-2), 1-18, 2008.

Grønlie, A. and Roberts, D.: Resurgent strike-slip duplex development along the Hitra-Snåsa and Verran faults, Møre-Trøndelag Fault Zone, Central Norway, J. Struct. Geol., 11, 295-305, 1989.

Grønlie, A., Harder, V., and Roberts, D.: Preliminary fission-track ages of fluorite mineralisation along fracture zones, inner Trondheimsfjord, Central Norway, Norw. J. Geol., 70, 173-178, 1990.

Grønlie, A., Nilsen, B., and Roberts, D.: Brittle deformation history of fault rocks on the Fosen Peninsula, Trondelag, central Norway, Norg. Geol. Unders. B., 421, 39-57, 1991.

Grønlie, A., Naeser, C. W., Naeser, N. D., Mitchell, J. G., Sturt, B. A., and Ineson, P.: Fission track and K/Ar dating of tectonic activity in a transect across the Møre-Trøndelag Fault Zone, Central Norway, Norw. J. Geol., 74, 24-34, 1994.

Hacker, B. R., Andersen, T. B., Johnston, S., Kylander-Clark, A. R. C., Peterman, E. M., Walsh, E. O., and Young, D.: Hightemperature deformation during continental-margin subduction and exhumation: The ultrahigh-pressure Western Gneiss Region of Norway, Tectonophysics, 480(1-4), 149, 2010.

Hagedoorn, J. G.: The plus-minus method of interpreting seismics refraction sections, Geophys. Prospect., 7, 158-182, 1959.

Hurich, C. A. and Roberts, D.: A seismic reflection profile from Stjørdalen to Outer Fosen, Central Norway: a note on the principal results, Norg. Geol. Unders. B., 433, 18-19, 1997.

Krabbendam, M. and Dewey, J. F.: Exhumation of UHP rocks by transtension in the Western Gneiss region, Scandinavian Caledonides, in: Continental Transpressional and Transtensional Tectonics, edited by: Holdsworth, R. E., Strachan, R. A., and Dewey, J. F., Geol. Soc. Lond., Special Publications, 135, 159-181, 1999.

Loke, M. H.: Tutorial: 2-D and 3-D electrical imagining surveys, 136 pp., 2004.

Lundberg, E. and Juhlin, C.: High resolution reflection seismic profiling over the Tjellefonna Fault in the Møre- Trøndelag Fault Complex, Norway, in prep., 2011. 
Lundberg, E., Nasuti, A., and Juhlin, C.: High resolution reflection seismic Profiling over the Møre- Trøndelag Fault Complex, Norway, Abstract, EGU Conference, Vienna, Austria, 2009.

Nasuti, A., Chawshin, K., Dalsegg, E., Tønnesen, J. F., Ebbing, J., and Gellein, J.: Electrical resistivity and refraction seismics over a segment of the Møre-Trøndelag Fault Complex, Norg. Geol. Unders. Report, 2009.037, 37 pp., http://www.ngu.no/upload/ Publikasjoner/Rapporter/2009/2009_037.pdf, 2009.

Nasuti, A., Beiki, M., and Ebbing, J.: Gravity and magnetic data acquisition over a segment of the Møre-Trøndelag Fault Complex, Norg. Geol. Unders. Report, 2010.049, 42 pp., http://www.ngu. no/upload/Publikasjoner/Rapporter/2010/2010_049.pdf, 2010a.

Nasuti, A., Ebbing, J., Pascal, C., Tønnesen, J. F. and Dalsegg, E.: Using geophysical methods to characterize a fault zone: a case study from the Møre-Trøndelag Fault Complex, Mid-Norway, Extended abstract, EAGE conference, Barcelona, 2010b.

Nettleton, L. L.: Determination of density for reduction of gravimeter observations, Geophysics, 4, 176-183, 1939.

Nielsen, S. B., Gallagher, K., Leighton, C., Balling, N., Svenningsen, L., Jacobsen, B. H., Thomsen, E., Nielsen, O. B., Heilmann-Clausen, C., Egholm, D. L., Summerfield, M. A., Clausen, O. R., Piotrowski, J. A., Thorsen, M. R., Huuse, M., Abrahamsen, N., King, C., Lykke-Andersen, H.: The evolution of western Scandinavian topography: A review of Neogene uplift versus the ICE (isostasy-climate-erosion) hypothesis, J. Geodyn., 47, 72-95, 2009.

Olesen, O., Brönner, M., Ebbing, J., Gellein, J., Gernigon, L., Koziel, J., Lauritsen, T., Myklebust, R., Pascal, C., Sand, M., Solheim, D. and Usov, S.: New aeromagnetic and gravity compilations from Norway and adjacent areas-methods and applications, in: Petroleum Geology: From mature basins to new frontiers, Proceedings of the 7th Petroleum Geology Conference, edited by: Vining, B. A. and Pickering, S. C., Geol. Soc. Lond., 7, 559-586, 2010.

Pascal, C. and Gabrielsen, R. H. Numerical modelling of Cenozoic stress patterns in the Mid Norwegian Margin and the northern North Sea, Tectonics, 20(4), 585-599, 2001.

Pascal, C. and Olesen, O.: Are the Norwegian mountains compensated by a mantle thermal anomaly at depth? Tectonophysics, 475, 160-168, 2009.

Pascal, C., Roberts, D., and Gabrielsen, R. H.: Tectonic significance of present-day stress relief phenomena in formerly glaciated regions, J. Geol. Soc., London, 167, 363-371, 2010.

Popowski, T., Connard, G., and French, R.: GM-SYS profile modeling, Gravity and Magnetic Modeling software for OasisMontaj - User Guide V4.1, 2009.

Redfield, T. F. and Osmundsen, P. T.: The Tjellefonna Fault system of Western Norway: Linking late-Caledonian extension, postCaledonian normal faulting, and Tertiary rock column uplift with the landslide-generated tsunami event of 1756 , Tectonophysics, 474, 106-123, 2009.
Redfield, T. F., Torsvik, T. H., Andriessen, P. A. M., and Gabrielsen, R. H.: Mesozoic and Cenozoic tectonics of the Møre Trøndelag Fault Complex, central Norway: constraints from new apatite fission track data, Phys. Chem. Earth, 10(29), 673-682, 2004.

Redfield, T. F., Osmundsen, P. T., and Hendriks, B. W. H.: The role of fault reactivation and growth in the uplift of western Fennoscandia, J. Geol. Soc., London, 162, 1013-1030, 2005.

Reynolds, J. M.: An Introduction to Applied and Environmental Geophysics, John Wiley \& Sons, New York, 796 pp., 1997.

Roberts, D. and Myrvang, A.: Contemporary stress orientation features in bedrocks, Trøndelag, central Norway, and some regional implications, Norg. Geol. Unders. B., 442, 53-63, 2004.

Robinson, P.: Extension of Trollheimen tectono-stratigraphic sequence in deep synclines near Molde and Brattvåg, Western Gneiss Region, southern Norway, Norsk Geol. Tidsskr., 75, 181198, 1995.

Scholz, C. H.: The Mechanics of Earthquakes and Faulting, Cambridge, $471 \mathrm{pp}$, http://www.cambridge.org/gb/knowledge/isbn/ item $1160996 /$ ?site_locale=en_GB, 2002.

Séranne, M.: Late Paleozoic kinematics of the Møre-Trøndelag Fault Zone and adjacent areas, central Norway, Norsk Geol. Tidsskr., 72, 141-158, 1992.

Skilbrei, J. R., Olesen, O., Osmundsen, P. T., Kihle, O., Aaro, S., and Fjellanger, E.: A study of basement structures and some onshore-offshore correlations in Central Norway, Norw. J. Geol., 82, 263-279, 2002.

Tucker, R. D., Krogh, T. E., Råheim, A.: Proterozoic evolution and age-province boundaries in the central part of the Western Gneiss region, Norway: results of U-Pb dating of accessoryminerals fromTrondheimsfjord to Geiranger, in: Mid-Proterozoic Laurentia-Baltica, GAC special paper, edited by: Gower, C. F., River, T., and Ryan, B., Geological Association of Canada, St. John's, Newfoundland, 38, 149-173, 1990.

Tveten, E., Lutro, O., and Thorsnes, T.: Berggrunnskart Ålesund, 1:250000, (Ålesund, western Norway), Geological Survey of Norway, Trondheim (bedrock map), 1998.

Watts, L. M.: The Walls Boundary fault zone and the MøreTrøndelag Fault Complex: a case study of two reactivated fault zones, Unpublished PhD thesis, Department of Geological Sciences, University of Durham, 2001.

Westerdahl, H.: Modellering av seismiske data over løsmassefylte depresjoner, svakhetssoner og ved kabelheng, Norges Geotekniske Institutt, Intern rapport, nr. 2338, 2003. 